\title{
HEAT FLOW PATTERNS OF THE NORTH AMERICAN CONTINENT: \\ A DISCUSSION OF THE DNAG GEOTHERMAL MAP OF NORTH AMERICA
}

\author{
David D. Blackwell, \\ John L. Steele, \\ and \\ Larry C. Carter \\ Department of Geological Sciences \\ Southern Methodist University \\ Dallas, Texas 75275
}

in Slemmons, D.B., Engdahl, E.R., Zoback, M.D., and Blackwell, D.D., eds., Neotectonics of North America: Boulder, Colorado, Geological Society of America, Decade Map Volume 1. 


\section{DISCLAIMER}

This report was prepared as an account of work sponsored by an agency of the United States Government. Neither the United States Government nor any agency Thereof, nor any of their employees, makes any warranty, express or implied, or assumes any legal liability or responsibility for the accuracy, completeness, or usefulness of any information, apparatus, product, or process disclosed, or represents that its use would not infringe privately owned rights. Reference herein to any specific commercial product, process, or service by trade name, trademark, manufacturer, or otherwise does not necessarily constitute or imply its endorsement, recommendation, or favoring by the United States Government or any agency thereof. The views and opinions of authors expressed herein do not necessarily state or reflect those of the United States Government or any agency thereof. 


\section{DISCLAIMER}

Portions of this document may be illegible in electronic image products. Images are produced from the best available original document. 


\section{ABSTRACT}

The large and small-scale geothermal features of the North American continent and surrounding ocean areas illustrated on the new 1:5,000,000 DNAG Geothermal Map of North America are summarized. Sources for the data included on the map are given. The types of data included are heat flow sites coded by value, contours of heat flow with a color fill, areas of major groundwater effects on regional heat flow, the top-ofgeopressure in the Gulf Coast region, temperature on the Dakota aquifer in the midcontinent, location of major hot springs and geothermal systems, and major centers of Quaternary and Holocenc volcanism. The large scale heat flow pattern that is well known for the conterminous United States and Canada of normal heat flow east of the Cordillera and generally high heat flow west of the front of the Cordillera dominates the continental portion of the map. However, details of the heat flow variations are also seen and are discussed briefly in this and the accompanying papers. Variations in heat flow east of the Cordillera are most commonly related to differences in the radiogenic heat production of the upper crust. The regional heat flow variations in the Cordillera are dominated by the effects of the subduction that has occurred along the west coast for the last 100 to 200 $\mathrm{Ma}$, and a band of generally low heat flow is typically located coastward of the broad band of high heat flow that represents the back-arc region and includes the much of the Cordillera west of the leading edge of late Mesozoic thin-skinned tectonics from the Bering Sea to southern Mexico. A thin belt of very high heat flow is characteristic of the volcanic arcs that occur between the outer-arc and back-arc regions. The subduction pattern is modified in many places by the superimposed effects of hot spot passage, transform faulting, and rapid extension.

\section{INTRODUCTION}

The objective in creating a geothermal map of North America was to show as accurately and completely as possible the state of knowledge of the geothermal field of the continent in all its variations. As a consequence, the types of information shown are combined in a way that is different from existing maps. The only other continent-wide map representations of aspects of temperature, geothermal gradient, or heat flow data are the AAPG/USGS Temperature Map of North America (1976) and the Gradient Map of North America (1976) both at a 1:5,000,000 scale.

Geothermal gradient maps of the United States have been prepared by Kron and Stix (1982) and Nathenson and Guffanti (1988). However, because both temperature and interval gradient can be calculated if the heat flow and lithology are known, the basic 
quantity that is needed is heat flow. Therefore these gradient maps have limited usefulness outside the range of direct observation. Numerous country-wide heat flow maps have been described for North America. However the knowledge of the thermal regime of North America has increased many fold in the last 10 to 15 years because of academic studies and because of the exploitation of geothermal energy and the associated resource studies. Thus it seemed to be an appropriate undertaking at this time to compile a continent-wide representation of the thermal field using this old and new knowledge. The preparation and publication of other continent-wide maps on a new digital base at the 1:5,000,000 scale is also part of the DNAG program. The common scale will allow direct areal comparison of several types of geological and geophysical information and this capability was also an important consideration in the decision to compile the geothermal map.

The basic background types of data shown on the new map are the heat flow sites with coded heat flow values, and a color pattern based on the heat flow contoured at $10 \mathrm{mWm}^{-}$ 2 intervals for the ocean and continental areas. The areas of the continental shelves are generally not included in the contouring because there are little heat flow data for those regions. In addition to the heat flow sites and color pattern, the locations of Quaternary volcanoes and major geothermal systems are indicated. Geothermal areas are shown with four different symbols. The areas are first subdivided based on whether the maximum temperature is above or below $150^{\circ} \mathrm{C}$, on the basis of temperatures either measured or inferred from geochemical studies. The second category is whether or not there is information in the literature documenting heat flow/geothermal gradient distributions based on the results of shallow exploration drilling and/or deep production drilling. A third major type of information shown involves areas with peculiar thermal characteristics, such as major areal effects on the conductive heat flow from groundwater flow. Also included in this group are contour and gray scale patterns indicating the temperature on the major thermal aquifer in the northcentral midcontinent region of the United States (the Dakota Sandstone), and the depth to the top of the geopressured zone in the Gulf Coast region.

References to the major sources of the various data are given in the map legend and more detailed information is given in this paper. Compilers of the heat flow data for various areas are also listed. The object of this paper is to give some of the background information on the map, to describe some of the decisions made in the compilation and contouring, and to summarize in a brief form some conclusions that can be drawn from the resulting map. More detailed discussions of Canada (Jessop, 1990a), the Canadian 
Cordillera (Lewis, 1990), the southwestern United States (Reiter and others, 1990), and the midcontinent region of the United States (Gosnold, 1990a) can be found in the accompanying papers in this volume.

The basic heat flow and ancillary data are available in compiled form. The point data base for the continent is available as one of the data sets (Blackwell and others 1989) on the GEOPHYSICS OF NORTH AMERICA CD-ROM published by NOAA. The data for eastern Canada as compiled by A. M. Jessop, for the Canadian Cordillera as compiled by Trevor Lewis, and for the remainder of the continent as compiled by the authors of this paper are included on that disk. The data included in the compilation for the United States are quite inclusive for individual heat flow sites including some data not in the original publications. The ideal database content is shown in Table 1. There is extensive information listed in addition to heat flow value and location. A complete reference list for the United States heat flow database is contained in Blackwell and others (1988) and a copy of the list can be obtained from the authors upon request. A subset of the information for each site is also contained in a world-wide heat flow compilation by Pollack and others (1990). The Pollack and others (1990) compilation also includes updated heat flow for the oceans. The compilation of oceanic heat flow values by Jessop and others (1976) as updated by Chapman and Furlong (1980) was used as the basic database for the oceans and updated by subsequent published data, most notably the addition of more continent-like data based on heat flow measurements in the holes drilled by the Deep Sea Drilling Program (Hyndman and others, 1987).

A very simplified index map for the continent-wide data is shown in Figure 1. The heat flow regions are taken from the 1:5,000,000 scale map with some modifications as described below. The basis for the heat flow contours in the oceans, not the values, are also shown on Figure 1. Reference to this map should be made as the discussion proceeds. The maps in this paper do not show the individual data points. These are shown on the 1:5,000,000 scale map. The most recent summaries of the heat flow in each area show most of the points (Sass and others, 1981 for Alaska; Jessop, 1990a for Canada; Morgan and Gosnold, 1989 for the United States; and Ziagos and others, 1985 for Mexico).

\section{OCEAN HEAT FLOW}

Pacific Ocean Because of the general correspondence of oceanic heat flow to the age of the oceanic lithosphere, and because of a general lack of a large heat flow data-set for the eastern part of the Pacific Ocean, the heat flow contours shown in that area are based on the age of the lithosphere inferred from the magnetic anomaly lineations (see Figure 1 for 
a division of the oceanic areas according to the contouring basis). The position of magnetic anomalies of appropriate ages was taken from the AAPG Plate-tectonic map of the circum-Pacific Basin (Drummond, 1981) and from the DNAG Magnetic Anomaly Map of North America (1987). The oceanic lithosphere age was determined at heat flow intervals of $10 \mathrm{mWm}^{-2}$ from 60 to $100 \mathrm{mWm}^{-2}$ and at 120 , and $150 \mathrm{mWm}^{-2}$ from the curve of Sclater and others (1980, Figure 4) based on a summary of the relationship of heat flow to lithospheric age for the oceans.

Near the ridge crests, convection is the dominant heat transfer mechanism, so within some distance of the ridge crest, the observed heat flow is usually significantly below the value predicted by the age versus heat flow relationship. Thus, for much of the area of the Pacific Ocean shown on the map, the actual measured heat flow values are lower than indicated by the contouring. This situation seems dominant in the Cocos plate where the measured heat flow values over almost all the area shown on the map are significantly below that predicted by the age versus heat flow relationship. The general pattern of low heat flow in this area has recently been documented by new data discussed by Prol Ledsma and others (1989). Along the ridge crests, of course, there are numerous high and intermediate temperature geothermal systems. These have proved to be so numerous that it did not seem worthwhile to indicate individual areas where the systems have been located at this time. The complexity of heat transfer near the ridge crests has been demonstrated in the map area for East Pacific rise and the Gulf of California as far north as the Guaymas Basin (e.g. Lonsdale and Becker, 1985) and for the Juan de Fuca ridge (Davis and Lister, 1977).

The area of the Juan de Fuca Plate is unique in that it is covered by sediment almost as quickly as the lithosphere is generated and therefore hot fluid outflow may not dominate the heat loss mechanism as much as it dominates in other areas of young lithosphere. Moran and Lister (1987) presented a detailed study of heat flow versus age for the Juan de Fuca Plate. This area is unusual because of the thick layer of sediment very near the ridge axis. Their locations are multiple penetration sites that have been carefully studied. Their results show heat flow values for sites that are only $150 \mathrm{~km}$ or more from the ridge crest that are close to the predicted heat flow for the age of the crust after corrections for sedimentation and other effects. This high heat flow and thick sediment cover in combination results in high temperatures for the top of the ocean basement. The high temperature of top of the basement as it is subducted beneath the North American plate is the primary reason for the low seismicity of the subducting lithosphere, not the thinness of the plate (Blackwell and others, 1982). 
Data on the continental shelves are not common, but where present have been contoured with the land measurements so the contours are based on observed data: Therefore there is generally a gap between the land/shelf data and the data in the oceans. There are a number of important scientific questions, such as the vertical distribution of heat production in the lithosphere, that could be addressed by data from the continental shelves. Perhaps such studies will be carried out in the future.

Atlantic Ocean In the Atlantic Ocean, as in the Pacific Ocean, the heat flow data have been contoured based on the age of the lithosphere. As a result, most of the Atlantic Ocean off the eastern United States is shown to have a heat flow between 40 and 50 $\mathrm{mWm}^{-2}$, while further to the east, the theoretical values are between 50 and $60 \mathrm{mWm}-2$. The age corresponding to the $50 \mathrm{mWm}^{-2}$ heat flow contour is about $63 \mathrm{Ma}$. The location of this age of lithosphere was taken from a map by Vogt and Einwich (1979) and the DNAG Magnetic Anomaly Map of North America (1987).

In general, in the area of the Atlantic Ocean southeast of the Labrador Sea shown on the map, the observed data on this relatively old, thickly sedimented, lithosphere are in quite close agreement with the predicted heat flow. A similar agreement in such settings has been illustrated to be typical of all ocean basins by Sclater et al. (1980).

An anomaly may be associated with the Bermuda Rise, which may be part of a hotspot track. Detailed studies in that area by Detrick and others (1986) document a slightly higher background heat flow in the vicinity of the Bermuda Rise. This area of higher heat flow has been indicated diagrammatically by a region of over $50 \mathrm{mWm}^{-2}$ heat flow values in an area of below $50 \mathrm{mWm}^{-2}$ heat flow based on the age versus heat flow relationship.

In the North Atlantic the heat flow data have also been contoured using the age inferred from interpretation of magnetic anomalies. The magnetic pattern is quite complicated and has been discussed in detail by Bott (1983) and by Nunns (1983). Their interpretations, as well as the magnetic anomalies shown on the DNAG Magnetic Anomaly Map of North America (1987), were used to reconstruct the theoretical position of the heat flow contours within this region. Measured heat flow data are quite sparse except just south of Iceland. The heat flow in the Laborador Sea is more problematical because there has been argument about the age of its opening (LePichon and others, 1971; Kristoffersen and Talwani, 1977). Within this area there are some heat flow observations, however, and the data agree in general with the contours shown that are in turn consistent with an age of opening in the center of the Laborador Sea between 46 and $63 \mathrm{Ma}$. Roest 
and Srivastava (1989) propose a similar age range for the opening although their orientation of the spreading is slightly different.

There have been extensive and intensive studies of the heat flow distribution in the Barbados accretionary sediment prism in the last few years. In some areas the heat flow is typical for the age of the ocean crust being subducted. In others there is evidence for fluid flow in the wedge (e.g. Langseth and others, 1988). As in the case of the ridges and land geothermal systems there is no attempt to show the details of such settings on the map. Gulf of Mexico and Caribbean Sea Heat flow contours in the Gulf of Mexico and the Caribbean Sea are based on observed data. The patterns that were observed cannot be closely related to the age of the sea-floor as in the case of the Atlantic and Pacific Oceans because diagnostic magnetic anomaly patterns have not been recognized in these areas to identify the age of the oceanic crust. Thus these areas were contoured based on the observed heat flow values.

There is a large area of moderate heat flow in the Caribbean Sea between the West Indies and Central America. This area is probably part of a back-arc high heat flow zone related to the subduction of the Atlantic lithosphere beneath the Caribbean Plate.

Within the Gulf of Mexico heat flow values are generally low in large part because of the high sedimentation rates, and particularly low heat flow values are observed off the Mississippi delta. If valid, these low values are probably related to the extremely high rate of sedimentation at the mouth of the delta. Some high values were found in the area of the Sigsbee Knolls, perhaps associated with the salt domes that underlie the uplifts.

Quite high heat flow values are observed in the Cayman Trough, the plate boundary between the North American plate and the Caribbean plate. These high values are consistent with the idea that a limited segment of ridge crest exists in this area. The age and characteristics of spreading at this ridge have been summarized by Rosencrantz and others (1988).

Arctic Ocean and Bering Sea Contours in the Arctic Ocean are based on observed heat flow values. The Arctic Ocean data have recently been summarized on a DNAG map (Wetmiller and others, 1989). The data shown in the Arctic Ocean are taken primarily from that map and references to the original data sources can be found in that publication. Heat flow in the part of the Arctic Ocean shown on the map is generally within the normal range and so is probably associated with lithosphere ages in excess of 50 to 60 Ma.

The contours in the Bering Sea are based on observed data. The heat flow is generally higher than the global average heat flow. The elevated heat flow is consistent with the 
back-arc setting and the heat flow in the parts of Alaska along strike of the subduction zone.

Iceland While not part of an ocean basin, the characteristics of heat flow and geothermal activity in Iceland have some similarities to the mid-ocean ridges. The Mid-Atlantic ridge crosses the island so that it is the site of active extension, volcanism, and geothermal activity. The heat flow is generally high. The heat flow values for the Geothermal Map of North America were calculated from a contoured geothermal gradient map of the island by Flovenz (1985) and the average thermal conductivity measured for the $1.9 \mathrm{~km}$ deep Reydarfjordur drill hole (Oxburgh and Agrell, 1982) was used in combination with the contoured gradient to calculate heat flow. The resulting heat flow map is certainly generalized, but interestingly shows some similarity to the inferred heat flow versus age values in the adjoining Atlantic Ocean. Major geothermal systems locations were taken from Flovenz (1985) and a review of high and low temperature geothermal fields by Arnorsson (1986). The locations of Quaternary volcanoes are from Simkin and others (1981).

\section{CONTINENTAL DATA}

Heat Flow Heat flow data available on the various land masses are plotted with a code that divides the data into $10 \mathrm{mWm}^{-2}$ intervals. Where there were multiple holes for a single reported site or multiple sites that would overlap at the scale of the map, the data were averaged and only a single value shown. Where data are of sufficient density they are contoured at a $10 \mathrm{mWm}^{-2}$ interval. Over much of the map there are insufficient data to constrain fully the contouring at that interval. However, a coarser interval would lose detail in the areas of high data density and is not fine enough to show some significant features. Therefore for consistency the $10 \mathrm{mWm}^{-2}$ interval was used for the whole map. The data sites are shown so that the user can evaluate the reliability of the contours in a particular area of interest as needed. In any event, the contouring must be viewed as preliminary and primarily as an attempt to aid in outlining areas of heat flow variation. Details of the contour pattern, unless based on data shown on the map must be treated as inference. In some cases contours follow known or presumed tectonic/physiographic/thermal trends in the absence of constraining heat flow data. Whether or not these interpretations are valid remains to be investigated by collection of additional data.

Many heat flow measurements have been made in Lake Superior using an oceanic approach with corrections for the effect of annual variations. There is significant variation in heat flow with position in the lake, but the size of the variations has not been 
corroborated with land data. There are no major conflicts with the land data, but the land data are sparse near the lake. For this reason the contours in the lake have not been carried onto the land and the lake data stand by themselves.

The contoured areas within the continents range from less than $20 \mathrm{mWm}^{-2}$ (in the Sierra Nevada Mountains) to greater than $120 \mathrm{mWm}^{-2}$ (in such areas as Yellowstone, the Salton Trough, etc). However, only small areas of these extremes are shown. The cause of the variations is generally volcano/tectonic disturbances in the lithosphere and variations in the radioactive heat generation of the crust. In a few areas more surficial factors affect the heat flow from the crust and mantle. The most common effect is rapid groundwater flow.

Fluid Flow In an attempt to delineate areas where large scale hydrologic disturbances of, or influences on, heat flow data are common, some areas of the map have an overprint. Where there is documentation that the heat flow by conduction from the earth's interior is disturbed by groundwater flow over large areas there is a gray overprint. This overprint is specialized in the case of a large area of the midcontinent region of the United States. In this area calculated temperatures on a specific aquifer are contoured at $10^{\circ} \mathrm{C}$ intervals. This aquifer is the Dakota Sandstone of Cretaceous age. The contouring is based on depth to the aquifer, combined with heat flow values logged wells in the region, and geographic information on the thermal conductivity of the section above the aquifer. The details are described in detail by Gosnold (1990a, 1990b). In large areas east of the Rocky Mountains, groundwater flow in the aquifer has a significant basin-wide effect on the heat flow. For example, the high values shown in northeastern Nebraska and eastern South Dakota (the area of heat flow values above $60 \mathrm{mWm}^{-2}$, the area labeled DA on Figure 2) probably are related to eastward flow (up dip) of warm water recharged at the west edge of the basin at high elevation exposures of the Dakota aquifer along the edges of the Black Hills and the Front Range (Gosnold, 1990a, 1990b).

In the case of the Snake Plain aquifer in Idaho (Brott and others, 1981) and the various aquifers in the Prairies Basin in Alberta (Majorowicz and others, 1984, 1985) the possibility of fluid flow influence on observed heat flow is indicated by a single density gray overprint. More details of the effect of the fluid flow on the heat flow can be found in these references. The heat flow estimates on which the contouring in Alberta is based are given by Beach and others (1987).

A somewhat different set of data is illustrated in the Gulf Coast in Texas and Louisiana by a gray shading with contours. In this case the depth to the top of the occurrence of geopressure is shown (Bebout and others, 1983). This depth is of interest 
from a geothermal point of view because the fluids from the geopressure zone may be produced and their thermal, mechanical, and hydrocarbon energy extracted (Wallace and others, 1979). Research and testing is underway to develop the technology to economically use this energy (Garg and others, 1981). In addition, the top of the geopressure zone is important as a zone of geothermal gradient change. Temperature gradients in the Gulf Coast generally range from 20 to $30^{\circ} \mathrm{C} / \mathrm{km}$ above the geopressure zone, while at the top of the zone the gradients often increase to 35 to $45^{\circ} \mathrm{C} / \mathrm{km}$ (see Bebout and others, 1979 for example). Where deep thermal data are available, gradients at depth eventually return to lower values of 20 to $25^{\circ} \mathrm{C} / \mathrm{km}$. For this reason, and because of the potential geothermal applications, the depth to the top of the geopressure zone is shown on the map. The contours of the top of the zone are from Bebout and others (1983) interpolated to contour intervals of $500 \mathrm{~m}$.

The origin of this change in gradient is controversial. It has been related to active fluid flow through the geopressure zone and/or to a low thermal conductivity for the shale that comprises the fluid seal. We favor the second explanation (Blackwell and Steele, 1989) in general. However, there is evidence for fluid flow both on the local (Wallace and others, 1979) and the large scale (Bodner and Sharp, 1988). A massive number of bottom hole temperature data exist for the Gulf Coast (e.g. Jam and others, 1969, Kron and Stix, 1982), but there are no published heat flow values for the area. We have estimated a value for a well near Houston on the Geothermal Map of North America. The temperaturedepth curve for this well is shown in Blackwell and Steele (1989).

Hot Springs; Geothermal Systems and Volcanic Centers In addition to the areas of aquifer effects on heat flow, information is shown on the location of major hot springs systems. Unfortunately simple plotting of all hot springs is not possible because no database of uniform quality is available for all areas of North America. We have attempted to select from the literature major geothermal systems as indicated by their size and/or temperature. Only the larger/hotter systems were selected for display in an attempt to produce a display that will be more uniform across the continent.

In the United States the geothermal systems were plotted from the compilation of Brook and others (1979). Major Quaternary volcanoes were also taken from the same publication (Smith and Shaw, 1979). The major hot springs and their reservoir temperatures in Canada were taken from data supplied by Jessop (personal communication, 1988) and the studies of Souther (1975) and Souther and Halstead (1973). Locations of Quaternary volcanic centers were taken from Mathews (1986). In Mexico the major geothermal systems plotted were selected on the basis of data in Prol- 
Ledsma and others (1986). The location and state of development of major geothermal systems in Central America is described by Dipoppo (1986). Quaternary volcanoes were taken from Simkin and others (1981).

In the past 10 years there has been extensive drilling in the vicinity of many geothermal systems to evaluate their potential for commercial exploitation of geothermal energy. Many short papers (or extended abstracts) have been published in the Transactions of the Geothermal Resources Council of Davis, California. A summary of references to temperature-depth data from geothermal areas is included in Blackwell and others (1988). In general the holes in the vicinity of geothermal systems are too closely spaced to be individually plotted on the 1:5,000,000 map scale. Geothermal systems with gradient and heat flow data in the public domain are indicated by a different symbol than the systems without data in the public domain.

Heat Production A major component of the thermal characteristics of a continental area is the heat production of the upper crust from radioactive isotopes of Uranium, Thorium, and Potassium. In plutonic terrains there is generally a linear relationship between the average radioactivity of the surface rocks and the heat flow in typical-depth drill-holes (Birch and others, 1968; Lachenbruch, 1968; and Roy and others, 1968). The implications of this relationship have been thoroughly discussed in the literature and the recent heat flow publications cited in this paper have many references to these discussions. The relationship is important in this discussion because the intercepts of the straight lines, the heat flow at zero heat production $\left(\mathrm{Q}_{\mathrm{r}}\right.$, the "reduced" heat flow), determined in different areas is in some way a measure of the deep heat flow i.e. the heat flow from the lower crust and mantle. Because this quantity varies much less than the measured surface heat flow $\left(\mathrm{Q}_{\mathrm{S}}\right)$, it is used to define as thermal provinces contiguous areas that have similar values of "reduced" heat flow (Roy and others, 1972). For example all of North America east of the Cordillera appears to have a similar $\mathrm{Q}_{\mathrm{r}}$ of $30 \pm 5 \mathrm{mWm}^{-2}$.

The heat production and the reduced heat flow are not shown on the Geothermal Map of North America to simplify the map presentation. However, the reduced heat flow for various areas will be used to discriminate different thermal provinces and mentioned as a characteristic parameter throughout this discussion. The index map in Figure 1 may be viewed in some sense as a simplified reduced heat flow map because thermal provinces are depicted on it.

\section{HEAT FLOW DISCUSSION-UNITED STATES}

Introduction Blackwell (1971), Roy and others (1972), Lachenbruch and Sass (1977), and Sass and others (1981) have given general summaries of the heat flow in the United 
States. Swanberg and Morgan (1980) used the silica geothermometer in an attempt to characterize areas with no heat flow data. General discussions focusing on the western United States have been given by Lachenbruch and Sass (1977) and Blackwell (1978). Because of these and many more area specific papers, such as the papers in this volume by Gosnold (1990b) and Reiter and others (1990), most of the larger scale thermal features are relatively well known.

Morgan and Gosnold (1989) have recently given a rather complete summary of the heat flow in various regions of the United States as developed in the last 10 years. The first object of this section is to supplement their discussion as it relates specifically to features shown on the geothermal map and not to repeat their summary. Thus Morgan and Gosnold (1989) should be read in conjunction with this section for a complete picture of United States heat flow. The second object of this discussion is to describe several features of the thermal pattern that are not well known, some of which are more easily recognized because of the detailed contour interval of the DNAG map.

Eastern United States A simplified heat flow map for the eastern United States is shown in Figure 2, based on the contours from the geothermal map. The contours are based on a total of 390 individual sites are included on the large scale heat flow map. Heat flow values are generally less than $60 \mathrm{mWm}^{-2}$ east of the Cordillera. The major exception to this generalization is in the Appalachian Mountains where higher than average heat flow values are associated with areas of high crustal radioactivity, such as in the White Mountains of New England (Birch and others, 1968; WM on Figure 2). Similar relatively high heat flow values in association with high crustal radioactivity are found in the southern Appalachians (Costain and others, 1986) and in the Maritime Provinces of Canada (Jessop, 1990a).

There is a band of lower than average heat flow (generally less than $40 \mathrm{mWm}^{-2}$ ) that roughly parallels to the west of the area of generally high heat flow in the Appalachians. It is not as easy, however, to associate this region with the cause, or causes, of the low heat flow. In New York the low heat flow is associated with low heat generation in the Proterozoic Grenville age anorthosite in the Adirondacks (Birch and others, 1968). The low heat flow in the central Appalachians might be associated with low crustal heat production or with regional redistribution of heat through large scale groundwater flow that is not measured by the available heat flow measurements (Smith and others, 1981). The data are not available to differentiate between these two hypotheses at the present time. The low heat flow values in Florida are probably related to aquifer effects because 
the measurements have been made in the extensive Floridan carbonate aquifer (Smith and Fuller, 1977).

In eastern Canada there is also low heat flow in the Grenville terrain according to recent heat flow determinations described by Mareschal and others (1989). Unfortunately all the measurements are in shallow holes in an area where climatic effects may be important to depths of several hundred meters. If the data are taken at face value the inference might be made that at least part of the low heat flow is associated with a crust that is generally low in heat production, possibly due to deep erosion and removal of upper crustal radioactive heat sources after the Precambrian collision of the Grenville terrain with North America.

In the Canadian Shield (Jessop, 1990a) and in the central stable region of the United States the heat flow is generally between 40 and $50 \mathrm{mWm}^{-2}$ and local heat flow depends on the local value of crustal heat production. The only anomalous area is in Arkansas and Louisiana where high heat flow values are found with no obvious explanation (Smith and Dees, 1982). Smith and Dees (1982) have proposed that structure (salt domes) might be part of the reason for the high heat flow.

The heat flow in the Great Plains in both the United States and Canada is complex. There are major perturbations to the crustal heat flow due to the flow of groundwater in the major regional aquifers such as the Cretaceous Dakota Sandstone (DA in Figure 2) in Colorado, Nebraska and the Dakotas, as mentioned above. The situation is also complex in the Prairies Basin area of Canada where there is much discussion of the role of fluid flow in the form of the observed heat flow pattern (Majorowicz and others, 1984, 1985; Jessop and Vigass, 1989; Bachu, 1988; Jessop, 1990b). Additional discussion and references are given by Jessop (1990a).

In spite of the many thousands of wells drilled in the Gulf Coast, as described above, there are few quantitative thermal data available. Discussions of bottom hole temperatures have been presented for some areas, but thermal conductivity data are rare. On a regional scale gradient decreases toward the Mississippi delta in southern Louisiana. This pattern also appears (weakly) in the available heat flow data. The most probable cause of this variation, if it is verified by further studies, is the cooling effects of the rapid sedimentation in the Gulf Coast Basin. A similar effect is seen in the data in the Gulf of Mexico. However, the thermal properties of the rocks in the basin are not known well enough to determine whether mechanisms such as sedimentation, regional changes in lithology, or basement structure are responsible for the effect. The second generalization that can be made concerning the Gulf Coast is that in the areas of geopressure, the 
gradient typically varies in relation to the top of the geopressured zone as described in the general map discussion above. The contours to the top of the geopressure zone are shown on the 1:5,000,000 scale map.

Western United States In contrast to the Eastern United States the factors that affect the heat flow in the western United States are of varying types, are complex, and overlap. While increased heat flow is often associated with tectonic activity, as in the oceans, in the western United States both high and low heat flow anomalies are associated with tectonism (see Morgan and Gosnold, 1989). Because of the added complexity, the regional heat flow patterns have been extensively studied. A total of 1428 separate sites, many representing more than one hole and also not counting the many multiple hole studies in geothermal systems, are shown on the map. A small scale section of the DNAG Geothermal Map of North America for the western United States with heat flow contours only is shown in Figure 3. The heat flow contours in $10 \mathrm{mWm}^{-2}$ intervals from the map are shown and the contours are patterned at $20 \mathrm{mWm}^{-2}$ intervals for clarity. The major areas of geothermal significance are indicated by abbreviations and the key to the abbreviations is given in the figure caption. The areas, either individually or in combination, can be classified into thermal provinces in most cases.

For example the largest province in the western United States includes the Northern Rocky Mountains (NR), Columbia Basin (CB), and Basin and Range province (B\&R) where the volcanism is older than about $17 \mathrm{Ma}$ (see Blackwell, 1978). All these areas have a heat flow from below the upper crustal radiogenic layer that is similar $(60 \pm 10$ $\mathrm{mWm}^{-2}$ ) and thus these areas comprise a thermal province in the sense of Roy and others (1972).

The Rio Grande rift (Reiter and others, 1990) and the Southern Rocky Mountains (Decker and others, 1988) have equal or higher heat flow from below the radiogenic layer. This area is geographically distinct and is discussed in more detail below.

Blackwell (1969) referred to the area of high heat flow encompassing the Basin and Range province and the Northern Rocky Mountains of the United States Pacific Northwest as the Cordilleran Thermal Anomaly Zone (CTAZ). In a subsequent analysis of the heat flow-heat production in the Basin and Range province Blackwell (1978) concluded that the $60 \pm 10 \mathrm{mWm}^{-2}$ intercept value was characteristic of areas with regional volcanism older than $17 \mathrm{Ma}$. More recent studies in Canada and Mexico mentioned below have found remarkably similar heat flow characteristics for the areas to the north and south along the Cordillera. 
Thermal subprovinces exist within this large area $f$ the western United States. Notable among these are the Eureka low (EL) and the Battle Mountain high (BM) in the Basin and Range province. Local and regional variation may be caused by fluid flow, local structural effects, heat production differences, presence of young volcanism and other types of effects.

Several other areas have heat flow that is equal to or in most cases higher than the CTAZ are the Salton Trough (ST), the Snake River Plain/Yellowstone region (SRP, Y), and the Cascade volcanic arc (CVA). The heat flow in the Salton Trough is high due to the extremely rapid extension (Lachenbruch and others, 1985) associated with the formation of an ocean ridge in the Gulf of California. The heat flow is high in the Snake River Plain/Yellowstone region due to the effects of the Yellowstone hot spot (see discussion below). The heat flow is variable, but generally very high, in the Cascade volcanic arc due to active mid-crustal intrusion there (Lewis and others, 1988; Lewis, 1990; Blackwell and others, 1990a, 1990b). The High Cascade Range of Oregon, the east half of the southern Cascade Range in Washington, and the part of the Cascade Range in British Columbia have very high heat flow and crustal temperatures.

West of these areas of high heat flow there is an almost continuous band of heat flow that is less than or equal to the heat flow in the stable eastern United States. This area includes the Western Cascade Range subprovince in Oregon, the coastal provinces in Oregon and Washington, the Klamath Mountains, Sierra Nevada Mountains, and the Peninsular Ranges in southern California. The Sierra Nevada Mountains as an area has the lowest $\mathrm{Q}_{\mathrm{r}}$ (only $20 \mathrm{mWm}^{-2}$ ) over a large region of a continent. It is even lower than the heat flow from below the upper crustal heat production layer in the Stable Interior $\left(30 \pm 5 \mathrm{mWm}^{-2}\right)$.

The low heat flow is due to the fact that a. subducting oceanic plate absorbs heat from the overlying wedge as it descends into the mantle. The heat flow is low from the trench to the edge of the volcanic arc. In contrast to the volcanic and back-arc regions, where penetrative convection of magma and extension are intracrustal sources, in the outer-arc the thermal regime in the crust is conductive. Therefore heat conduction theory can be utilized to calculate the thermal recovery after subduction stops in an area such as the Sierra Nevada Mountains due to triple point migration along the coast (see Atwater, 1970). The heat flow in the Sierra Nevada Mountains and Peninsular Ranges in southern California and in northern Baja California is consistent with heating from the bottom and sides of the cold block after the termination of subduction. The Salinian block (SB) does 
not fit this pattern because the heat flow is high in this Mesozoic plutonic terrain west of the San Andreas fault.

In fact all along the gap in the volcanic arc along the west coast of the conterminous United States the heat flow rises again west of the low heat flow that is the remnant of the early and mid-Cenozoic subduction pattern. This area is coincident with the extent of the San Andreas fault zone. The high heat flow east of the San Andreas and west of the Sierra Nevada Mountains is attributed to the effects of the hole in the plate (see the model described by Lachenbruch and Sass, 1980; and Zandt and Furlong, 1982). The Clear Lake volcanic center, site of The Geysers geothermal field, is the late-Cenozoic location of the migrating volcanism along the east side of the San Andreas that may coincide with the migrating "hole".

Surprisingly the heat flow is also high along the west side of the fault zone in the granitic terrain of the Salinian block (SB) as well. Because this block was probably in an outer arc position analogous to the Peninsular Ranges and Sierra Nevada Mountains as recently as $5 \mathrm{Ma}$ ago the heat flow was low before the position of the San Andreas fault jumped inland about $5 \mathrm{Ma}$ ago. Yet its present day surface and reduced heat flow are similar to the Basin and Range province. The block is wide enough that it should not have heated up from the sides, and judging from the example of the other two blocks it should not yet have heated up from the bottom. A possible resolution of this inconsistency is that the cold block is thinner because the cold mantle part of the Salinian block is delaminated from the crustal block as it moves northward and is deformed around the bend in the fault zone at the Transverse Ranges. A deep, high velocity, high density, "root" in the upper mantle beneath the Transverse Ranges has been inferred on the basis of seismic and gravity data (Hadley and Kanamori, 1977; Sheffels and McNutt, 1986). If the anomaly is due to cold upper mantle that is being stripped from the base of the Salinian block as it goes around the bend in the San Andreas, then the crust alone could heat up in a few millions of years.

Whatever the explanation, the heat flow is high on both sides of the San Andreas fault and there is no peak of over $10 \mathrm{mWm}^{-2}$ over the fault zone as should occur if there is significant frictional loss of heat in the seismogenic zone of the fault (see Lachenbruch and Sass, 1980, 1990). This lack of an anomaly has led to the hypothesis that the fault zone is weak (Zoback and others, 1987). The situation is of enough interest to spawn the drilling of a $4 \mathrm{~km}$ well to test the properties and heat flow of the fault zone at depth. Preliminary results of the drilling have been presented by Zoback and others (1988) and the heat flow from the well has been described by Sass and others (1990). 
A third more or less north trending area of high heat flow in the western United States occurs in the Rio Grande rift subprovince (RG) of the Basin and Range province and in the Southern Rocky Mountains (SR). This north-south trending zone is bounded on the east by the Great Plains (GP) province with generally normal continental heat flow except in areas disturbed by aquifer flow as described above. On the west the bounding province is the Colorado Plateau (CP), with normal heat flow in spite of its high average elevation. This area has surface and reduced heat flow that is equal to or greater than the values for the CTAZ. The detailed characteristics of the two areas are described in Reiter and others (1990) and Decker and others (1988). Of particular interest is evidence for contemporary magma chambers in both areas.

The Rio Grande rift is the most difficult heat flow province to fit into a subduction related category. The high heat flow east of the normal heat flow in the Colorado Plateau makes a simple back-arc setting doubtful. One possible scenario is a very low angle of subduction in the Oligocene from the coast to the east edge of the Colorado Plateau followed by a steep angle to form the San Juan volcanics as a volcanic arc. Reactivation of the still warm region by late Cenozoic extension related to triple point effects (Atwater, 1970) could explain the high heat flow in New Mexico. However, the reduced heat flow is as high or higher in Colorado where extension is minor to nonexistant.

The north edge of the high heat flow in the Southern Rocky Mountains is quite abrupt with a half width of $50 \mathrm{~km}$ (Decker and others, 1988). The heat flow in the Wyoming Basin (WB) and the Middle Rocky Mountains (MR) to the north (and east of the CTAZ) is similar to that in the craton, with a surface heat flow of $50 \mathrm{mWm}^{-2}$ and a reduced heat flow of $30 \pm 5 \mathrm{mWm}^{-2}$. The heat flow boundary almost coincides with the Archean/Proterozoic boundary between the Wyoming craton and the Southern Rocky Mountains Proterozoic terrain (about 1420-1500 my zircon ages, Bickford and others, 1986). Morgan (1985) proposed that Archean cratons have survived without experiencing major tectonism because the heat production is lower for these old cratons, and hence the lithosphere is thicker, than for younger crusts. In Africa, Ballard and others (1987) found evidence for a thermal effect associated with the Archean terrains and inferred fundamental heat flow differences between Archean and younger terrains. It is interesting that the Archean Wyoming craton has had a completely different tectonic history than any of the other areas in the Cordillera. While crustal compression has affected the area, volcanism and extension have not. The explanation may be related to the peculiarities of the plate tectonic interactions, but it may also be related to the nature 
of Archean cratons. Further investigation of this question would seem to be a useful line of research.

The Snake River Plain/Yellowstone area (SP, Y) is a major thermal and tectonic province of the western United States. Its original geological and geophysical characteristics have been completely overprinted in the late Cenozoic by a sequence of thermally dominated features related to passage of a hot spot (currently situated under the Yellowstone caldera) as described by Brott and others (1981). Of particular interest is the development of a regional topographic profile due to lithospheric thermal contraction that is very similar to the ocean ridge topographic profile. The heat flow in this area is generally above $100 \mathrm{mWm}^{-2}$ (Blackwell, 1989).

\section{HEAT FLOW DISCUSSION-NORTH AMERICA}

There are several overall patterns that appear when the heat flow data for the whole continent are plotted and contoured. The general differences in heat flow between the stable eastern and the tectonically active western part of the continent are obvious. General continent-wide relationships of heat flow with age have been extensively explored (Sclater and others, 1980, Vitorello and Pollack, 1980, and Morgan and Sass, 1984). As pointed out by Morgan and Sass (1984), these average relations become more complicated in actual applications to specific North American terrains.

A very generalized heat flow map of North America is shown in Figure 1. At this scale the major patterns that stand out are the normal heat flow in the eastern part of the continent and the variable heat flow in the western part of the continent associated with the Cordillera. General aspects of the heat flow in Canada have been described by Jessop (1990a) and general aspects of the heat flow in the Canadian Cordillera have been discussed by Lewis (1990). The heat flow in Mexico has been discussed by Ziagos and others (1985) and by Prol-Ledsma and others (1989). A sketch of the heat flow pattern in Alaska has been given by Sass and others (1981). In both areas there are broad regions characterized by high heat flow bounded on the west by regions of low heat flow. The heat flow in the part of Siberia on the map is normal based on the measurements described by Duchkov (1985). Only four heat flow regimes are delineated on Figure 1. These are regions with heat flow less than $40 \mathrm{mWm}^{-2}, 40$ to $70 \mathrm{mWm}^{-2}, 70$ to $90 \mathrm{mWm}^{-}$ 2 and greater than $90 \mathrm{mWm}^{-2}$. Since the areas outlined are based on conductive heat transfer from the crust and upper mantle, areas disturbed by large scale fluid flow are not shown as they are on the 1:5,000,000 scale map. Furthermore because of the small scale some areas of no data are included in the characterized areas. In a general way these areas 
can also be categorized on the basis of their reduced heat flow $\left(\mathrm{Q}_{\mathrm{r}}\right)$. The four areas are characterized by $\mathrm{Q}_{\mathrm{r}}$ values of $<25,30 \pm 5,60 \pm 10$ and $>60 \mathrm{mWm}^{-2}$.

At this scale the eastern and central parts of North America are characterized by uniform and normal heat flow. Variations in heat flow are shown on the 1:5,000,000 scale map but not on Figure 1 because the dominant cause of heat flow variations is differences in radiogenic heat production in the upper crust and the whole area is thought to have the same upper mantle and lower crustal heat flow (about 25 to $30 \mathrm{mWm}^{-2}$ ). However, the areas within the Cordillera of Western North America are quite different. All values of regional heat flow, from the lowest to the highest are found there. About $75 \%$ of the area of the Cordillera is characterized by heat flow values in the range of 70 and $90 \mathrm{mWm}^{-2}$. The heat flow distribution is well established for the United States, for Mexico north of the TransMexico Volcanic Belt, and for the Southern Canadian Cordillera. The patterns shown for the northern Canadian Cordillera, and for interior Alaska (Sass and others, 1981) are based on sparse data.

Where radioactivity data exist, the heat flow-heat production lines are characterized by intercept values at zero heat production of $60 \pm 10 \mathrm{mWm}^{-2}$. Such areas include the Sierra Madre Oriental and Occidental in Mexico (Smith and others, 1979), much of the Basin and Range province in the United States (Roy and others, 1972, Blackwell, 1978), the Northern Rocky Mountains, Columbia Basin and Blue Mountains in the northwestern United States, and the southern Canadian Cordillera in British Columbia (Lewis and others, 1985).

As noted above, Blackwell (1969) referred to the area of high heat flow as then known (the Basin and Range province and the Northern Rocky Mountains of the United States Pacific Northwest) as the Cordilleran Thermal Anomaly Zone (CTAZ). In a subsequent analysis of the heat flow-heat production in the Basin and Range province Blackwell (1978) concluded that the $60 \pm 10 \mathrm{mWm}^{-2}$ intercept value was characteristic of areas with regional volcanism older than $17 \mathrm{Ma}$. More recent studies in Canada and Mexico have found remarkably similar heat flow characteristics for the areas to the north and south along the Cordillera. Furthermore the correspondence of the eastern part of the region of high heat flow to the area characterized by decollement type of supracrustal deformation in the latter half of the Mesozoic is striking (see Drewes, 1978). The eastern border of this region, with minor exceptions, also defines the areas of Cenozoic volcanic activity in the Cordillera.

The area of high heat flow is bordered along its west side by areas of generally higher heat flow in the volcanic arcs that exist where subduction is still occurring off the west 
coast. West of the volcanic arcs, and west of the CTAZ where there are no contemporary volcanic arcs, such as the Sierra Nevada Mountains, there is a more or less continuous band of low heat flow. This band of low heat flow is the outer arc of the subduction zone. 'Because heat flow is conductive in the crust and mantle above the slip zone, the heat flow takes several millions of years to recover when subduction stops, unless an active heat source is present. The low heat flow in the areas of western north America where no subduction is occurring today are remnants of the previous time when subduction was continuous along the whole west coast (Atwater, 1970).

Areas of higher heat flow within this larger area include the Battle Mountain region in Nevada, parts of the Cascade volcanic arc, parts of the Southern Rocky Mountains, and the Snake River Plain/Yellowstone region. As discussed above, the high heat flow of the volcanic arc and the Snake River Plain/Yellowstone area is related to arc volcanism and hot spot activity respectively. An area of similar heat flow includes parts of California in the vicinity of the San Andreas fault. This area is also not related to the CTAZ in the sense that the high heat flow there is not back-arc related.

In order to illustrate the categories of origins for the heat flow anomalies in the western Cordillera the various areas discussed are shown in Table 2. The various provinces shown in Figures 2 and 3, and equivalent areas in Canada, Alaska and Mexico, are listed in the table as one axis and the various types of anomalous areas are listed on the second axis. Most of the areas fall into one of the three categories related to subduction listed in Table 2. In the case of some areas in Mexico and Alaska, the association is by geological type of province rather than measured heat flow because of lack of data in those areas.

The continent-wide view emphasizes the rather similar thermal characteristics of the Cordillera along strike and the extent to which these characteristics are related to the subduction process that has dominated the tectonics of the region for the last $100 \mathrm{Ma}$ or more. Much of the interior region of the Cordillera apparently has had high heat flow for at least 70 to $100 \mathrm{Ma}$, and the broad patterns that persist to today; especially the eastern border of the high-heat flow back-arc zone, may have been established at that time. The major modifications of the pattern up to about 30 ma may have been the variations of the width of the low-heat flow outer-arc block as the slab subducted angle changed. After 30 Ma changes were associated with the fragmentation of the outer-arc zone associated with triple point movements, but the basic thermal pattern has been remarkably stable. 


\section{ACKNOWLEDGMENTS}

The map compilation was supported by the USDOE through contract ID/12623. Support for some aspects of the compilation also came from SMU. Part of the support for the preparation of this paper came from the National Science Foundation under grant EAR-8817176. Sidney Baker assisted in the data compilation and Kris Eckhardt helped in the preparation of this manuscript. Paul Morgan and Shari Kelley made helpful comments on the manuscript.

\section{REFERENCES CITED}

American Association of Petroleum Geologists and U. S. Geological Survey, 1976, Geothermal gradient map of North America: U. S. Geological Survey, $1: 5,000,000$.

American Association of Petroleum Geologists and U. S. Geological Survey, 1976, Subsurface temperature map of North America: U. S. Geological Survey, $1: 5,000,000$.

Arnorsson, S., 1986, Chemistry of gases associated with geothermal activity and volcanism in Iceland: A review: Jour. Geophys. Res., v. 91, p. 12261-12268.

Atwater, T., 1970, Implications of plate tectonics for the Cenozoic tectonic evolution of western North America: Geol. Soc. Amer. Bull., v. 81, 3513-3536.

Bachu, S, 1989, Analysis of heat transfer processes and geothermal pattern in the Alberta Basin, Canada: Jour. Geophys. Res., v. 93, p. 7767-7781

Ballard, S., Pollack, H.N., Skinner, N.J., 1987, Terrestrial heat flow in Botswana and Namibia: Jour. Geophys. Res., v. 92, p. 6291-6300.

Beach, R.D.W., Jones, F.W., and Majorowicz, J.A., 1987, Heat flow and heat generation estimates for the Churchill basement of the western Canadian basin in Alberta, Canada: Geothermicsn v. 16, p. 1-16.

Bebout, D.G., Weise, B.D., Gregory, A.R., and Edwards, M.B., 1979, Wilcox sandstones in the deep subsurface along the Texas Gulf Coast, their potential for production of geopressured energy: Texas Bureau Economic Geol., DOE Report ET28461, $219 \mathrm{pp}$.

Bebout, D.G., Bassiouni, Z., Carver, D.R., Groat, C.G., Johnson, A.E., Jr., and Wrighton, F.M., 1983, Technical support for geopressured-geothermal well activities in Louisiana: Annual Report DOE/NV/10174-2, 454 p.

Bickford, M.E., Van Schmus, W.R., and Zietz, I., 1986, Proterozoic history of the midcontinent of the region of North America: Geology, v. 14, p. 492-496. 
Birch, F., Roy, R.F., and Decker, E.R., 1968: Heat flow and thermal history of New York and New England, in Zen, E., White, W.S., Hadley, J.B., and Thompson, J.B., Jr., eds., Studies of Appalachian geology; Northern and Maritime: New York, Interscience, p.437-451.

Blackwell, D.D., 1969, Heat flow in the northwestern United States: Jour Geophys. Res., v. 74, p. $992-1007$.

Blackwell, D.D., 1971, The thermal structure of the continental crust, in Heacock, J.G., ed., The structure and physical properties of the Earth's crust: American Geophys. Union Mono. 14, p 169-184.

Blackwell, D.D., 1978, Heat flow and energy loss in the Western United States, pp. 175208, in Cenozoic Tectonics and Regional Geophysics of the Western Cordillera, ed. R.B. Smith and G.P. Eaton, Geol. Soc. Amer. Mem 152, 388 pp.

Blackwell, D.D., 1989, Regional implications of heat flow of the Snake River Plain, northwestern United States: Tectonophysics, v. 164, p. 323-343 .

Blackwell, D.D., and Steele, J.L., 1989, Thermal conductivity of sedimentary rocks: Measurement and significance: in Naeser, N.D., and McCulloh, eds., Thermal history of sedimentary basins: Methods and case histories, New York, SpringerVerlag, p. 13-36.

Blackwell, D.D., and Steele, J.L., eds., 1990, Geothermal map of North America: Boulder, Colo., Geol. Soc. Amer. 4 sheets, 1:5,000,000.

Blackwell, D.D., Steele, J.L., and Carter, L.C., 1988, Geothermal Database and Oregon Cascade thermal studies, Southern Methodist University, DOE Final Report DOE/ID/12623-1, $90 \mathrm{pp}$.

Blackwell, D.D., Steele, J.L., and Carter, L.C., 1989, Heat flow data base for the United States, in Hittleman, A.M., Kinsfather, J.O., and Meyers, H., eds., Geophysics of North America CD-ROM: Boulder, CO, Natl. Oceanographic and Atmospheric Adm., Natl. Geophys. Data Center.

Blackwell, D.D., Steele, J.L., Kelley, S.A., and Korosec, M., 1990a, Heat flow in the state of Washington and thermal conditions in the Cascade Range: Jour. Geophys. Res., in press.

Blackwell, D.D., Steele, J.L., Frohme, M.K., Murphy, C.F., Priest, G.R., and Black, G.L., 1990b, Heat flow in the Oregon Cascade Range and its correlation with regional gravity, Curie point depths, and geology: Jour. Geophysical Res., in press. 
Blackwell, D.D., Bowen, R.G., Hull, D.A., Riccio, J., and Steele, J.L., 1982, Heat flow, arc volcanism, and subduction in northern Oregon: Jour. Geophys. Res., v. 87, p. 8769-8754.

Bodner, D.P., and Sharp, J.M., Jr., 1988, Temperature variations in south Texas subsurface: Amer. Association Petrol. Geol. Bull., v. 72, p. 21-32.

Bott, M.H.P., 1983, Deep structure and geodynamics of the Greenland-Scotland Ridge: An introductory view, pp. 3-10, in Bott, M.H.P., Saxon, S., Talwani, M., and Thiede, J., ed., Structure and Development of the Greenland-Scotland Ridge: N.Y., Plenum Press, 685 p.

Brook, C.A., Mariner, R.H., Mabey, D.R., Swanson, J.R., Guffanti, M., and Muffler, L.P.J., 1979, Hydrothermal convection systems with reservoir temperatures $90^{\circ} \mathrm{C}$ : in Muffler, L.J.P., ed., Assessment of geothermal resources of the United States1978, U. S. Geol. Survey Circular 790, p. 18-85.

Brott, C.A., Blackwell, D.D., and Ziagos, J.P., 1981, Thermal and tectonic implications of heat flow in the eastern Snake River Plain, Idaho: Jour. Geophys. Res., v. 89, p. 11709-11734.

Chapman, D.S., and Furlong, K., 1980, The world heat flow data collection-1980: unpublished compilation.

Committee for the Magnetic Anomaly Map of North America, 1987, Magnetic Anomaly Map of North America: Boulder, Colo., Geol. Soc. Amer. 4 sheets, 1:5,000,000.

Costain, J.K., Speer, J.A., Glover, L., III, Perry, L., Dashevsky, S., and McKinney, M., 1986, Heat flow in the Piedmont and Atlantic Coastal Plain of the southeastern United States: Jour. Geophys. Res., v. 91, p. 2123-2135.

Davis, E.E., and Lister, C.R.B., 1977, Heat flow measured over the Juan De Fuca ridge: Evidence for widespread hydrothermal circulation in a highly heat transportive crust: Jour. Geophys. Res., v. 82, p. 4845-4860.

Decker, E.R., Heasler, H.P., Buelow, K.L., Baker, K.H., and Hallin, J.S., 1988, Significance of past and recent radioactivity studies in the Southern Rocky Mountains: Geol. Soc. Amer. Bull., v. 100, pp 1851-1885.

Detrick, R.S., VonHerzen, R.P., Parsons, B., Sanwell, D., and Dougherty, M, 1986, Heat flow observations on the Bermuda Rise and thermal models of midplate swells: Jour. Geophys. Res., v. 91, pp 3701-3723.

Dipippo, R., 1986, Geothermal energy developments in Central America: Geothermal Resources Council Bulletin, v 15, n. 10, p3-13. 
Drewes, H., 1978, The Cordilleran orogenic belt between Nevada and Chihuahua: Geol. Soc. Amer. Bull., v. 89, p. 641-657.

Drummond, K.J., chairman., 1981, Plate-tectonic map of the circum-Pacific region:

Northeast quadrant: Tulsa, OK, Amer. Assoc. Petrol. Geol., 1:10,000,000.

Duchkov, A. D., 1985, Katalog dannyh po teplovomu potoku Sibiri: Novosibirsk.

Florenz, O.G., 1985, Application of subsurface temperature measurements in geothermal prospecting in Iceland, Jour. Geodynamics, v. 4, pp 331-340.

Garg, S.K., Riney, T.D., and Fwu, J.M., 1981, Analysis of phase I flow data from Pleasant Bayou No. 2 geopressured well: Trans. Geothermal Resources Council, v. 5, p. 693-696.

Gosnold, W.D., Jr, 1990b, Heat flow in the Great Plains of the United States, Jour. Geophys. Res., v. 95, pp. 353-374.

Gosnold, W.D., Jr, 1990a, Subsurface temperatures in the northern Great Plains: This volume.

Hadley, D.M., and Kanamori, H., 1977, Seismic structure of the Transverse Ranges, California: Jour. Geophys Res., v. 88, p. 1469-1478.

Hyndman, R.D., Langseth, M.G., VonHerzen, R.P., 1987, Deep sea drilling project geothermal measurements: A review, Rev. of Geophys., v. 25, pp 1563-1582.

Jam, P.L., Dickey, P.A., and Tryggvason, E., 1969, Subsurface temperature in south Louisiana: Amer. Assoc. Petrol._Geol. Bull., v. 53, p. 2141-2149.

Jessop, A.M., 1990a, Terrestrial heat flow in Canada: This volume.

Jessop, A.M., 1990b, Comparison of industrial and high resolution thermal data in a sedimentary basin: Pageoph., v. 133, p. 251-267.

Jessop, A.M., and Vigass, L.W., 1989, Geothermal Measurements in a deep well at Regina, Saskatchewan: Jour. Volcan. and Geothermal Res., v. 37, p. 151-166.

Jessop, A.M., Hobart, M.A., and Sclater, J.G., 1976, The world heat flow data collection1975: Energy, Mines, and Resources Canada Geothermal Series No. 5, 125pp.

Klitgord, K.D., and Schouten, H., 1986, Plate kinematics of the central Atlantic, pp. 351378, in Tucholke, B.E., and Vogt P.R., eds, The Western North Atlantic Region: Geol. Soc. Amer., The geology of North America, v. M.

Kristoffersen, Y., and Talwani, M., 1977, Extinct triple junction south of Greenland and the Tertiary motion of Greenland relative to North America: Geol. Soc. Amer. Bull., v. 88, p. 1037-1049. 
Kron, A., and Stix, J., 1982, Geothermal gradient map of the United States Exclusive of Alaska and Hawaii: Denver, CO, Natl Geophys. Data Center, Natl. Oceanic and Atm. Adm., scale 1:2,500,000.

Lachenbruch, A.H., and. Sass, J.H, 1977, Heat flow in the United States and the thermal regime of the crust: in Heacock, J.G., ed., The nature and physical properties of the Earth's crust, Amer. Geophys. Union Geophys. Mon. 20, p. 626-675.

Lachenbruch, A.H., and Sass, J.H., 1980, Heat flow and energetics of the San Andreas fault zone: Journal of Geophysical Research, v. 90, p. 6185-6222.

Lachenbruch, A.H., and Sass, J.H., 1990, Heat flow from Cajon Pass, fault strength, and tectonic implications: Jour. Geophysical Res., in press.

Lachenbruch, A.H., Sass, J.H., and Galanis, S.P., Jr., 1985, Heat flow in southernmost California and the origin of the Salton trough: Journal of Geophysical Research, v. 90, p. 6709-6736.

Langseth, M.G., Westbrook, G.K., and Hobart, M.A., 1988, Geophysical survey of a mud volcano seaward of the Barbados Ridge accretionary complex: Jour. Geophys. Res., v. 93, p. 1049-1061.

LePichon, X, Hyndman, R.D. Pautot, G., 1971, Geophysical study of the opening of the Labrador Sea: Jour. Geophys. Res., v. 26, pp. 4724-4743.

Lewis, T.J., 1990, Heat flux in the Canadian Cordillera: This volume.

Lewis, T.J., Jessop, A.M., and Judge, A.S., 1985, Heat flux measurements in southwestern British Columbia: The thermal consequences of plate tectonics: Canadian Jour. Earth Sciences, v. 22, p. 1262-1273.

Lewis, T.J., Bentkowski, W.H., Davis, E.E., Hyndman, R.D., Souther, J.G., and Wright, J.A., 1988, Subduction of the Juan de Fuca plate: Thermal consequences: Jour. Geophysical Res., v. 93, p. 15207-15225.

Lonsdale, P., and Becker, K., 1985, Hydrothermal plumes, hot springs, and conductive heat flow in the southern trough of the Guaymas Basin: Earth and Planetary Sci. Letters, v. 73, p. 211-225.

Mareschal, J.C., Pinet, J., Gariepy, C., Jaupart, J., Bienfait, G., Dalla Coletta, G., Jolivet, J., and Lapointe, R., 1989, New heat flow density and radiogenic heat production data in the Canadian shield and the Quebec Appalachians: Canadian Jour. Earth Sci., v. 26, p. 845-852.

Majorowicz, J.A., Jones, F.W., Lam, H.L., and Jessop, A.M., 1984, The variability of heat flow both regional and with depth in southern Alberta, Canada; Effect of ground-water flow: Tectonophysics, v. 106, p. 1-24. 
Majorowicz, J.A., Jones, F.W., Lam, H.L., and Jessop, A.M., 1985, Terrestrial heat flow and geothermal gradients in relation to hydrodynamics in the Alberta Basin; Canada: Jour. Geodynamics, v. 4, p. 265-283.

Mathews, W.H. (Compiler), 1986, Physiographic map of the Canadian Cordillera: Geol. Survey of Canada Map 1701A, 1:5,000,000.

Moran, J.E., and Lister, C.R.B., 1987, Heat flow across Cascadia Basin near $47^{\circ} \mathrm{N}$, $128^{\circ} \mathrm{W}$ : Jour. Geophys. Res., v. 92, pp.11416-11432.

Morgan, P., 1985, Crustal radiogenic heat production and the selective survival of ancient continental crust: Jour. Geophysical Res., v. 90, supplement, p. C561-C570.

Morgan, P., and W.D. Gosnold, 1989, Heat flow and thermal regimes in the continental United States, pp. 493-522, in Pakiser, L.C., and Mooney, W.D., Geophysical framework of the continental United States: Boulder, Colo., Geol. Soc. Amer. Memior 172.

Morgan, P., and Sass, J.H., 1984, Thermal regime of he continental lithosphere: Jour. Geodynamics, v. 1, p. 143-166.

Nathenson, M., and Guffanti, M., 1988, Geothermal gradients in the conterminous United states: Jour. Geophys. Res., v. 93, p. 6437-6450.

Nunns, A.G., 1983, Plate tectonic evolution of the Greenland-Scotland Ridge and surrounding regions, pp. 11-30, in Bott, M.H.P., Saxon, S., Talwani, M., and Thiede, J., ed., Structure and Development of the Greenland-Scotland Ridge: N.Y., Plenum Press, 685 p.

Oxburgh, E.R., and Agrell, S.O., 1982, Thermal conductivity and temperature structure of the Reydarfjordur borehole: Jour. Geophys. Res., v. 87, pp. 6423-6428.

Pollack, N., Johnson, J.R., and Harter, S.J., 1990, Global heat flow data compilation: Boulder, Colo, Natl. Oceanographic and Atmospheric Adm., Natl. Geophys. Data Center, in press.

Prol-Ledsma, R.M., and Juarez M.G., 1986, Geothermal map of Mexico: Jour. Volcan. and Geothermal Res., v. 28, p. 351-362.

Prol-Ledsma, R.M., Sugrobov, V.M., Flores, E.L., Juarez, G., Smirnov, Ya. B., Gorshkov, A.P., Bondarenko, V.G, Rashidov, V.A., Nedopekin, L.N., and Garilov, V.A., 1989, Heat flow variations along the Middle America Trench: Marine Geophys. Res., v. 11, p. 69-76.

Reiter, M., Barroll, and Minier, J., 1990, An overview of heat flow in southwestern United States and Chihuahua, Mexico: This volume. 
Roest, W.R., and Srivastava, S.P., 1989, Sea-floor spreading in the Laborador Sea: A new reconstruction, Geology, v. 17, pp. 1000-1003.

Rosencrantz, E., Ross, M.I., and Sclater, J.G., 1988, Age and spreading history of the Cayman Trough as determined from depth, heat flow, and magnetic anomalies: Jour. Geophys. Res.; v. 93, p. 2141-2147.

Roy, R.F., Decker, E.R., Blackwell, D.D., and Birch, F., 1968, Heat generation of plutonic rocks and continental heat flow provinces: Earth and Planetary Science Letters, v. 5, p. 1-12.

Roy, R.F., Blackwell, D.D., and Decker, E.R., 1972, Continental heat flow, in Robertson E.C., ed., The nature of the solid earth: New York, McGraw-Hill, p. 506-543.

Sass, J.H., Lachenbruch, A.H., Moses, T.H., Jr., and Morgan, P. 1990, Heat flow from a scientific research well at Cajon Pass, California: Jour. Geophysical Res., in press.

Sass, J.H., Blackwell, D.D., Chapman, D.S., Costain, J.K., Decker, E.R., Lawver, L.A., and Swanberg, C.A., 1981, Heat flow from the crust of the United States, pp. 503548, in Touloukian, T.S., Judd, W.R., and Roy, R.F., ed., Physical properties of rocks and minerals: New York, Vol. II-2, McGraw H.V., CINDUS Data Series on Material Properties, 503-548.

Sclater, J.G., Jaupart, C., and Galson, D., 1980, The heat flow through oceanic and continental crust and the heat loss of the earth: Rev. Geophys. Space Phys., v. 18, pp. 269-311.

Sheffels, B., and McNutt, M., 1986, Role of subsurface loads and regional compensation in the isostatic balance of the Transverse Ranges, California: Evidence for intercontinental subduction: Jour Geophys. Res., v. 91, p. 6419-6431.

Simkin, T., Siebert, L., McClelland; L., Bridge, D., Newhall, C., and Latter, J.H., 1981, Volcanoes of the world: A regional directory, gazetteer, and chronology of volcanism during the last 10,000 years: Stroudsburg, PA, Hutchinson Ross Pub. Co.

Smith, D.L., and Dees, W.T., 1982, Heat flow in the Gulf Coastal Plain: Jour. Geophys. Res., v. 87, p. 7687-7693.

Smith, D.L., and Fuller, W.R., 1977, Terrestrial heat flow values in Florida and the effects of the aquifer system; in The Geothermal Nature of the Floridan Plateau, Florida Bureau of Geology Special Pub.,p. 91-130.

Smith, D.L., Gregory, R.G., and Emhof, J.W., 1981, Geothermal measurements in the southern Appalachian Mountains and southeastern Costal Plain: Amer. Jour. Science, v. 328, p. 282-298. 
Smith, D.L., Nuckels, C.E., Jones, R.L., and Cook, G.A., 1979, Distribution of heat flow and radioactive heat generation in northern Mexico: Jour. Geophys. Res., v. 84, p. 2371-2379.

Smith, R.L., and Shaw, H.R., 1979, Igneous-related geothermal systems: in Muffler, L.J.P., ed., Assessment of geothermal resources of the United States-1978, U. S. Geol. Survey Circular 790, p. 12-18.

Souther, J.G., 1975, Geothermal potential of Western Canada, pp. 259-267, in Second U.N. Symp. on the Dev. and Use of Geothermal Resources, v. 1, U.S. Gov. Printing Office, Washington, D.C., 3 vols.

Souther, J.G., and Halstead, E.C., 1973, Mineral and thermal waters of Canada, Canada Dept. Energy, Mines, and Resources Paper 73-18, 1973.

Swanberg, C.A., and Morgan, P., 1980, The silica heat flow technique; Assumptions and applications: Jour. Geophys. Res., v. 85, p. 7206-7214.

Talwani, M., and Eldholm, O., 1977, Evolution of the Norwegian-Greenland Sea, Geol. Soc. Amer. Bull., v. 88, pp, 969-999.

Vitorello, I., and Pollack, H.N., 1980, On the variation of continental heat flow with age and the thermal evolution of continents: Jour. Geophys. Res., v. 85, p. 983-995.

Vogt, P.R., and Einwich, A.M., 1979, Magnetic anomalies and sea-floor spreading in the western Atlantic, and a revised calibration of the Keathly $(\mathrm{M})$ geomagnetic reversal chronology: in Initial Reports of the Deep Sea Drilling Project, v. 43, eds. B.E. Tucholke and P.R. Vogt, U. S. Government Printing Office, Washington D.C., p. 857-867.

Wallace, R.H., Jr., Taylor, R.E., and Wesselman, J.B., 1977, Use of hydrogeologic mapping techniques in defining potential geopressured-geothermal reservoirs in the lower Rio Grande embayment, Texas, in Meriwether, J., ed., Proceedings, Third geopressured geothermal energy conference: Lafayette, Lou., Univ. Southwestern Louisiana Center for Energy Studies, p. GI1-88.

Wallace, R.H., Jr., Kraemer, T.F., Taylor, R.E., and Wesselman, J.B., 1979, Assessment of geopressured-geothermal resources in the northern Gulf of Mexico basin: in Muffler, L.J.P., ed., Assessment of geothermal resources of the United States1978, U. S. Geol. Survey Circular 790, p. 132-155.

Wetmiller, R.J., Langseth, M.G., Marshall, D.V., Lachenbruch, A.H., 1989, Seismicity and heat flow of the Arctic: Plate 2, v. L, Geology of North America, Geol. Soc. Amer., in press. 
Zandt, G., and Furlong, K.P., 1982, Evolution and thickness of the lithosphere beneath coastal California: Geology, v. 10, p. 376-381.

Zoback, M.D., Silver. L.T., Henyey, T., and Thatcher, W., 1988, The Cajon Pass scientific drilling experiment: Overview of phase 1: Geophys. Res. Letters, v. 15, p. 933-936.

Zoback, M.D., Zoback, M.L., Mount, V.S., Suppe, J., Eaton, J.P., Healy, J.H., Oppenheimer, D., Reasenberg, P., Jones, L., Raleigh, C.B., Wong, I.G., Scotti, O., and Wentworth, C., 1987, New evidence on the state of stress of the San Andreas fault system: Science, v. 238, p. 1105-1111.

Ziagos, J.P., Blackwell, D.D., and Mooser, F., 1985, Heat flow and subduction in southern Mexico: Jour. Geophys. Res., v. 90, p. 5410-5420. 


\section{FIGURE CAPTIONS}

Figure 1. Index map for the DNAG Geothermal Map of North America. Areas of oceans with contours based on age are shown by the wave pattern. Areas of oceans with contours based on observed heat flow are shown by the open dot pattern. Areas of continent with heat flow that is normal (Qs of $50 \mathrm{mWm}^{-2}$, Qr of $30 \mathrm{mWm}^{-2}$ ) are shown by the intermediate density dot pattern. Areas of heat flow equal to, or below, normal in tectonic areas are shown by the low density dot pattern. Areas of heat flow that are typical of the CTAZ ( $\mathrm{Q}_{\mathrm{S}}$ of $80 \mathrm{mWm}^{-2}, \mathrm{Q}_{\mathrm{r}}$ of $60 \mathrm{mWm}^{-2}$ ) are shown by the high density dot pattern. Areas with very high heat flow (generally greater than $100 \mathrm{mWm}^{-2}$ ) are shown by the cross hatched pattern.

Figure 2. Heat flow map for the eastern United States. The contours are from the DNAG Geothermal Map of North America and are shown at $10 \mathrm{mWm}^{-2}$ intervals. Each band of heat flow is shown by a different pattern. Abbreviations are explained in the text. Figure 3. Heat flow map for the western United States. The contours are from the DNAG Geothermal Map of North America and are shown at $10 \mathrm{mWm}^{-2}$ intervals. Each pattern covers a $20 \mathrm{mWm}^{-2}$ interval. Abbreviations refer to areas discussed in the text. 
Table 1. Description of heat flow data-base in Blackwell and others (1989).

A. Description of 80 column "card image" format.

LOCATION (CARD 1)

-1
$-9 M S$ MAP

INFORMATION-STATUS (CARD 2)

$\gg>>>><\}\}\}\{>>><@\}\}\}\{\{>>><<\}\}\{\{=1==1=>>><<\}\}\}\}\{>>>><X X X X X X X X X-==-=X X X X X X$

ELEV DMAX DWAT TSUR TMAX TMIN JOBDATE BHT PAGE BAGE (BLANK) PUB

RESULTS (CARD TYPE 3)

$>>>><\}\}\}\}\{>><@\}\{\{-->>><@\}\}\{>>><@\}\}\{>>><<@\}\{>><<@\}\{\{->><@\}\{\{-->><<X X X X X X X X X X X X$ RNG1 RNG2 TCU SE N UNGR SE COGR SE UNHF SE COHF SE Q HP SE N

GEOLOGY (CARD TYPE 4)

COMMENTS (CARD TYPE 5)

\section{AMS MAP \\ HOLE \\ DATE \\ TS-RN-SEC \\ ST, $P$ \\ LAT, LONG \\ ELEV}

DMAX, DWAT

TSUR

TMAX, TMIN, BHT

JOBDATE

PAGE, BAGE

PUB

RNG1, RNG2

TCU

SE

$\mathrm{N}$

UNGR, COGR

UNHF, COHF

$\mathrm{O}$

HP

\section{B. Eplaination of fields \\ "Card 1"}

Name of 1:250,000 scale map covering site

Hole name or identifier

Date hole was logged

Township location

Codes identifing state and physiographic province

Latitude and longitude location

Elevation of hole collar

"Card 2"

Maximium depth logged and depth to water table

Temperature at surface (extraoplated)

Maximun, minimum and bottom hole temperatures

Date hole was completed

Age of province and basement

Reference to source of data

\section{"Card 3"}

Upper and lower depth interval for heat flow Average thermal conductivity in interval

Standard error of preceeding average quantity

Number of thermal conductivity samples

Uncorrected and corrected gradient in interval

Uncorrected and corrected heat flow in interval

Code for quality, or error of measurement

Heat production 
Table 2. Generalized heat flow setting of various areas of characterized heat flow in the western North America. The abbreviations OA and Ba refer to outer arc and back arc respectively.

Province or Area

Heat Flow
Normal Low(OA) High(BA) Vol Arc Other

East of Cordillera $\mathrm{X}$

Southern Rocky Mountains/RGR

Wyoming Basin/Middle RM

Colorado Plateau

Basin and Range

Northern Rocky Mountains (US)

Brooks Range (?)

Columbia Basin

High Lava Plains/Blue Mtns

Interior Plateaus (Canada)

Yukon Plateaus

Sierra Madre Oriental*

Sierra Madre Occidental

Sierra Nevada/Great Valley

U. S. Northwest Coast

Vancouver Island, Fjords

Peninsular Ranges of S. Calif.

Northern Baja California

Sierra Madre del Sur (Mexico)

Cascade Range

Aleutian Range

TransMexico Volcanic Belt

Salton Trough

Snake River Plain/Yellowstone

San Andreas (east side)

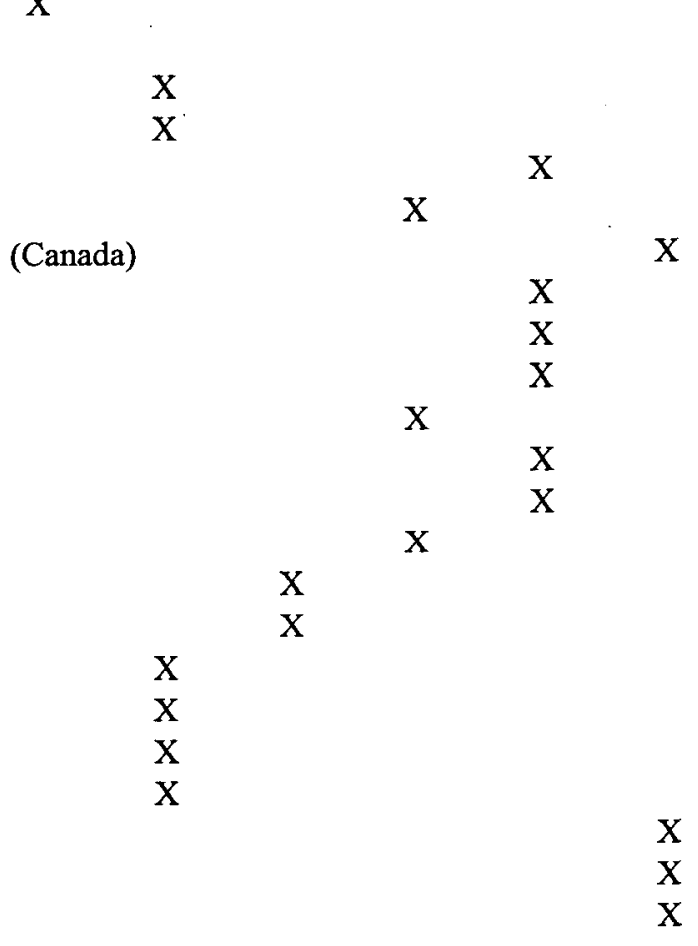

$\mathrm{X}$ ?

$\mathrm{X}$

$\mathrm{X}$

$\mathrm{X}$

(west side: Salinia)

Hot Spot

Slab Hole(?)

Extension

${ }^{*}$ North of the TransMexico volcanic belt 